\title{
The Role of Construction Management Consultants in Building Construction Procurement with Integrated Construction Method
}

\author{
Rubby Missilia Dwiaryanti1, Dwi Dinariana2, Fitri Suryani3 \\ Postgraduate Student of Master of Civil Engineering Program, Persada Indonesia University-YAI, Jakarta \\ ${ }^{2.3}$ Lecturer of Master of Civil Engineering Program, University of Persada Indonesia University-YAI, Jakarta
}

DOI: 10.29322/IJSRP.11.09.2021.p11717

http://dx.doi.org/10.29322/IJSRP.11.09.2021.p11717

\begin{abstract}
Designing and building in developed and developing countries such as Singapore, Malaysia, Hong Kong and other neighboring countries apply the integrated method (Design and Build) as an alternative development method. In Indonesia, the integrated method (Design and Build) is mostly used for infrastructure construction work, but in recent years the integrated method (Design and Build) is also used in building construction works. The research entitled "The Role of Construction Management Consultants in Building Procurement with Integrated Construction Methods" has a problem formulation of how the role of construction management consultants is important for achieving quality, time, cost and administrative procedures (Auditable) and can be carried out properly and correctly so that benefits can be achieved. The purpose of this study is to determine the role of construction management consultants in procurement activities using integrated construction methods. The research procedure is a qualitative research which is taken from the main data of the research object.
\end{abstract}

Keywords- Construction Management, Building Procurement, Integrated Construction Method, Government Regulation on Integrated Construction Method.

\section{INTRODUCTION}

The role of construction management consultant services in the procurement of physical construction services, especially in the preparation of technical documents for procurement/tenders/auctions with integrated construction methods is one of the factors that support the sustainability of a project, so that construction activities can run well. Problems that occur when construction procurement takes place in an integrated construction method based on the completeness of the technical documents for procurement/tenders/auctions, so it is necessary to carry out an analysis carried out by a construction management consultant.

\section{LITERATURE REVIEW}

\section{a. GOVERNMENT REGULATIONS}

1) Regulation of the Minister of Public Works Number 14/PRT/M/2013 concerning the Second Amendment to the Regulation of the Minister of Public Works Number 07/PRT/M/2011 concerning Standards and Guidelines for Procurement of Construction Works and Consulting Services is listed in the Appendix. Compiled based on Presidential Regulation number 70 of 2012 concerning the Second Amendment to Presidential Regulation Number 54 of 2010 concerning Government Procurement of Goods/Services. Regulation of the Minister of Public Works and Public Housing Number 19/PRT/M/2015 concerning Standards and Guidelines for Procurement of Integrated Design and Build Construction Works (Design and Build). Compiled based on Presidential Regulation number 54 of 2010 which was last amended by Presidential Regulation Number 4 of 2015 concerning the Fourth Amendment to Presidential Regulation Number 54 of 2010 concerning Government Procurement of Goods/Services.

2) Regulation of the Minister of Public Works and Public Housing Number 19/PRT/M/2015 concerning Standards and Guidelines for Procurement of Integrated Design and Build Construction Work (Design and Build) needs to be replaced by regulating the needs planning stage, procurement preparation, up to the handover of goods/services which changed to Regulation of the Minister of Public Works and Public Housing Number 12/PRT/M/2017 Regulation of the Minister of PUPR concerning Standards and Guidelines for Procurement of Integrated Design and Build Construction Works (Design And Build). 
3) Regulation of the Minister of Public Works and Public Housing of the Republic of Indonesia No. 1 of 2020 concerning Standards and Guidelines for the Procurement of Integrated Design and Build Construction Works through Providers; then there is a change.

4) Regulation of the Minister of Public Works and Public Housing of the Republic of Indonesia No. 25 of 2020 concerning Amendments to the Regulation of the Minister of Public Works and Public Housing Number 1 of 2020 concerning Standards and Guidelines for Procurement of Integrated Construction Works through Design and Build Providers

\section{b. PREVIOUS RESEARCH}

1) Procurement of Goods and Services for Construction Works and Consulting Services (exposure to seminar activities by the Director of Construction Services Implementation in 2016)

2) Application of Design and Build Methods on Building Projects in Bali, AA Diah Parami Dewi, ST., MT., Ph.D, 2015

3) Determinants of the Success of Design and Build Projects, Bambang E Yuwono, 2008

4) Study on the Implementation of System Design Build in Private Property Projects, Krishna S Pribadi' ${ }^{1}$, Biemow Soemardi ${ }^{1}$, Bambang Yuwono ${ }^{2}, 2004$

5) Identification of Risk Factors for Design And Build Projects at PT. XYZ Affecting Time Performance, Toni Alam, 2011

\section{METHODOLOGY}

\section{a. RESEARCH STRATEGY}

The research procedure that is suitable for this research is qualitative research which is taken from primary data from the research object. The research method used is the Delphi method. "The Delphi method is a systematic method of collecting opinions from a group of experts through a series of questionnaires, where there is a feedback mechanism through a 'round' of questions that is held while maintaining the anonymity of the responses of respondents (experts)." (Foley, 1972). This Delphi method is used to filter data to generate agreement. Furthermore, by giving questionnaires to resource persons/experts, then data processing is carried out using SPSS, namely to test validity and reliability tests, so that the resulting data is expected to be valid and consistent data.

\section{b. RESEARCH ALOGARITH}

Research Approach:

1) Conduct a literature study from books, journals and other related parties to formulate problems and find a theoretical basis that supports this research.

2) Formulate the research objectives and based on the framework of thinking, a hypothesis is developed which will be the basis of the research

3) Establish a research strategy, namely the interview method with resource persons

4) Determining research variables based on literature review and compiling questionnaires (research instruments)

5) In accordance with the research strategy, the data was collected by interviewing resource persons

6) Making conclusions that answer the research objectives

7) Write a report

\section{c. METHOD OF COLLECTING DATA}

1) Data 1

\begin{tabular}{|c|l|}
\hline CODE & \multicolumn{1}{c|}{ VARIABLE } \\
\hline X1 & $\begin{array}{l}\text { Construction management consultants in work with integrated methods are included in the } \\
\text { procurement stage for integrated contractors in accordance with the Minister of Public Works } \\
\text { Regulation No. 45/KPTS/M/2007 dated December 27, 2007 regarding Technical Guidelines for } \\
\text { State Building Construction and updated by Minister of PUPR Regulation No. 22/PRT/M/2018 } \\
\text { and the People's Housing of the Republic of Indonesia No. 25 of 2020 concerning Amendments } \\
\text { to the Regulation of the Minister of Public Works and Public Housing Number 1 of 2020 } \\
\text { concerning Standards and Guidelines for Procurement of Integrated Construction Works through } \\
\text { Design and Build Providers? }\end{array}$ \\
\hline X2 & $\begin{array}{l}\text { Construction management consultant at the stage of procurement of integrated contractors in the } \\
\text { Minister of PUPR Regulation No. 25 of 2020 includes the stage of Design and Build work } \\
\text { preparation activities / integrated? }\end{array}$ \\
\hline
\end{tabular}




\begin{tabular}{|c|c|}
\hline X3 & $\begin{array}{l}\text { Construction management consultants must be supported by personnel in engineering fields who } \\
\text { have good competence? } \\
\text { Among others : } \\
\text { Architectural Experts, Structural Experts, Geotechnical Experts, Mechanical Experts, Electrical } \\
\text { Experts, Electronic Experts, Plumbing Experts, Interior Experts, Quantity Surveyor Experts }\end{array}$ \\
\hline $\mathrm{X} 4$ & $\begin{array}{l}\text { Construction management consultants together with topographic specialists at the stage of } \\
\text { procurement of integrated contractors to prepare technical geological map data for the work site } \\
\text { ? }\end{array}$ \\
\hline $\mathrm{X} 5$ & $\begin{array}{l}\text { Construction management consultants and specialists in sondir and boring at the stage of } \\
\text { procurement of integrated contractors preparing soil/geological investigation data for locations } \\
\text { closest to the work? }\end{array}$ \\
\hline X6 & $\begin{array}{l}\text { The construction management consultant at the procurement stage of the integrated contractor } \\
\text { determines some of the soil test points (as an initial reference) from the total soil test based on } \\
\text { SNI? }\end{array}$ \\
\hline $\mathrm{X} 7$ & $\begin{array}{l}\text { Construction management consultants at the stage of procurement of integrated contractors define } \\
\text { the scope of work clearly and in detail? }\end{array}$ \\
\hline X8 & $\begin{array}{l}\text { Construction management consultants together with employers, building users and the building } \\
\text { maintenance department at the stage of procurement of integrated contractors make design } \\
\text { criteria? }\end{array}$ \\
\hline X9 & $\begin{array}{l}\text { Construction management consultants at the stage of procurement of integrated contractors make } \\
\text { standard work to be carried out? }\end{array}$ \\
\hline $\mathrm{X} 10$ & $\begin{array}{l}\text { Construction management consultants at the stage of procurement of integrated contractors make } \\
\text { quality standards? }\end{array}$ \\
\hline X11 & $\begin{array}{l}\text { Construction management consultants at the stage of procurement of integrated contractors make } \\
\text { technical provisions for other service users? }\end{array}$ \\
\hline $\mathrm{X} 12$ & $\begin{array}{l}\text { Construction management consultants at the stage of procurement of integrated contractors } \\
\text { identify and allocate project risks? }\end{array}$ \\
\hline X13 & $\begin{array}{l}\text { Construction management consultants at the stage of procurement of integrated contractors } \\
\text { identify and identify land requirements? }\end{array}$ \\
\hline $\mathrm{X} 14$ & $\begin{array}{l}\text { Construction management consultants at the stage of procurement of integrated contractors make } \\
\text { basic drawings, schematic drawings, cut drawings, typical drawings and other drawings? }\end{array}$ \\
\hline X15 & $\begin{array}{l}\text { At the stage of procurement of integrated contractors in the activities of making basic drawings, } \\
\text { schematic drawings, cut drawings, typical drawings and other drawings, construction } \\
\text { management consultants are strengthened by expert personnel with competence in the planning } \\
\text { field. }\end{array}$ \\
\hline X16 & $\begin{array}{l}\text { Construction management consultant at the stage of procurement of integrated contractors } \\
\text { reviewing the budget ceiling? }\end{array}$ \\
\hline $\mathrm{X} 17$ & $\begin{array}{l}\text { If you agree, is the construction management consultant in reviewing the budget ceiling } \\
\text { strengthened by a team of quantity surveyors who have a certificate of expertise? }\end{array}$ \\
\hline X18 & $\begin{array}{l}\text { Construction management consultants at the stage of procurement of integrated contractors make } \\
\text { predictions of the activity period in the form of a project timeline? }\end{array}$ \\
\hline $\mathrm{X} 19$ & $\begin{array}{l}\text { Do you have any input regarding the above variables which are documents that must be } \\
\text { prepared/made by a construction management consultant for building works with an integrated } \\
\text { method? }\end{array}$ \\
\hline
\end{tabular}

2) Data 2

To find out about integrated construction projects at the construction procurement stage using an construction management consultant or using a technical team. This data is obtained from the information of experts.

\section{RESULTS}

1. Respondents absolutely agree that the role of construction management consultants at the stage of building procurement using an integrated method in accordance with the Regulation of the Minister of Public Works and Public Housing of the Republic of Indonesia No. 25 of 2020 concerning Amendments to the Regulation of the Minister of Public Works and Public Housing Number 1 of 2020 concerning Standards and Guidelines for Procurement of Integrated Construction Works of Design and Build Through Providers, this is in accordance with the results of respondents on variable X1. 
2. Respondents unanimously agreed that at the construction procurement stage the role of construction management is required in accordance with the Regulation of the Minister of Public Works and Public Housing of the Republic of Indonesia No. 25 of 2020, this is in accordance with the results of the respondents on the X2 variable.

3. Respondents absolutely agree that construction management consultants must be supported by personnel in engineering fields who have good competence. Among others: Architectural Experts, Structural Experts, Geotechnical Experts, Mechanical Experts, Electrical Experts, Electronic Experts, Plumbing Experts, Interior Experts, Quantity Surveyor Experts, this is in accordance with the results of respondents on variable X3.

4. Most of the respondents agreed that the construction management consultant together with topographic specialists at the procurement stage of the integrated contractor prepared the technical geological map data for the work location, according to the results of the respondents in the $\mathrm{X} 4$ variable. The respondents who did not agree submitted some inputs/comments as follows:

A. At the time of procurement, simple data can be obtained from the owner of the job or from outside.

B. Usually the project owner already has a workforce that specializes in this field. Most of these owners work with consultants who specialize in geology.

C. No need, soil test data and soil data alone are sufficient.

5. Most of the respondents agreed that construction management consultants and specialists in sondir and boring at the stage of procurement of integrated contractors prepared soil/geological investigation data for the location closest to the work, according to the results of respondents on variable X5. The respondents who did not agree submitted some inputs/comments as follows:

A. No need for specialists, let alone secondary data.

B. This is because the owner who prepares the land data is carried out by the owner who appoints a separate provider specifically to prepare the initial data for the concept of the order during the auction or the procurement of an integrated provider.

6. Most of the respondents agreed that the construction management consultant at the procurement stage of the integrated contractor determined some of the soil test points (as an initial reference) from the total soil test based on SNI, in accordance with the results of respondents on variable X6. The respondents who did not agree submitted some inputs/comments as follows:

A. Because it is not the scope of construction management work, but it can be done by a special consultant for the preparation of basic designs as auction materials for integrated design providers.

B. Determination of the soil test point is the authority of the planning institution under the integrated contractor.

7. Most of the respondents agree that the construction management consultant at the stage of procurement of integrated contractors makes the standard of work to be carried out, this is in accordance with the results of the respondents on variable $\mathrm{X} 9$. The respondents who did not agree submitted some inputs/comments as follows:

A. Not setting standards but referring to the standards issued by the authorized agency.

B. The standard of work to be carried out is already the responsibility of the owner, it can be done by selfmanagement or by involving a special planning consultant for basic design only.

8. Most of the respondents agree that the construction management consultant at the stage of procurement of integrated contractors makes quality standards, this is in accordance with the results of respondents on the X10 variable. The respondents who did not agree submitted some inputs/comments as follows:

A. Not setting standards but referring to the standards issued by the authorized agency.

9. Respondents absolutely agree that construction management consultants at the stage of procurement of integrated contractors make technical provisions for other service users, this is in accordance with the results of respondents on variable X11.

10. Most of the respondents agreed that the construction management consultant at the procurement stage of the integrated contractor made the identification and allocation of project risks. In accordance with the results of the respondents on the X12 variable. The respondents who did not agree submitted some inputs/comments as follows:

A. Construction management does not identify and allocate project risks, but warns of the risks that will occur.

11. Most of the respondents agreed that at the stage of procurement of integrated contractors in the activities of making basic drawings, schematic drawings, cut drawings, typical drawings and other drawings, construction management consultants were strengthened by expert personnel with competence in the field of planning. This is in accordance with the results of the respondents on the X15 variable. The respondents who did not agree submitted some inputs/comments as follows:

A. Not too absolute.

B. Construction management prior to being used as an Integrated Contractor Procurement Document.

C. Created by the planning consultant for the design concept.

D. Except in the construction management consultant contract, there is a provision that the construction management consultant must work together with the schematic design planning team, or must do KSO 
with the schematic planning institution. Construction management consultants do not have planning authority. This is important because the involvement of a construction management consultant will have conflicting responsibilities with the planner of the integrated contractor.

E. Not in accordance with the scope of work of construction management in PERMEN No. 22, because construction management worked at the beginning only as input and assisting in reviewing basic design documents.

12. Respondents absolutely agree that the construction management consultant at the stage of procurement of integrated contractors makes predictions of the activity period in the form of a project timeline. This is in accordance with the results of the respondents on the X18 variable.

13. Respondents absolutely agree that there is input related to the above variables which are documents that must be prepared/made by a construction management consultant for building work with an integrated method. This is in accordance with the results of the respondents on the X19 variable. The inputs given by the respondents are as follows:

A. Actually all systems already exist and are good, the important thing is that the integrity of all personnel must be maintained properly, from preparation, implementation to inspection/audit.

B. Licensing must run simultaneously: DB permit from the Minister/Governor, while other permits from Owner: environmental permit, building permit, and others.

C. In general, the Constitutional Court has responsibilities during the Pre Tender/preparatory period including:

i. Preparation of TOR Design \& Build

ii. Preparation of Design Criteria

iii. Ceiling calculation/ review

iv. Basic Design

v. Assist the Selection team in making a Dock Draft. Qualifications and Doc. Election

vi. In Contract Implementation Stage:

1) Carry out implementation control and quality assurance of Construction work (Quality Assurance)

2) Verify the bill of payment

3) Assist and provide input to the Task Giver regarding matters of contract changes, asset calculations, and audit assistance.

D. Possibility of a construction management consultant to prepare a Design concept using the Competition system with conformity limits to the Planning Constraints and Available Budget Constraints

E. The selection of the Integrated Design and Build contractor is carried out with a Beauty Contest pattern with an agreed assessment limit between the Service User, PPK and other Technical Teams

F. Use of Value Engineering Steps to build Budget harmonization on Integrated Contractor bidding and Planning development with the target of Budget optimization and Green Construction

G. What must be prepared in addition to the documents listed in this research variable are the integrated Contractor Procurement/Selection Document which was prepared together with the Working Group, as well as the assessment method for the prospective Integrated Contractor.

H. All documents are prepared by a construction management consultant who has a certificate of expertise.

I. The composition of the BOQ that will be submitted to the bidders must be considered regarding the price per $\mathrm{m} 2$ because it cannot be broken down when there will be an amendment.

J. Initial documents that need to be prepared for building work with an integrated method, especially for the purposes of procurement/procurement of integrated contractors, as well as those generated from the construction management consultant's guide, in the form of detailing all forms of preferences from employers, building users and maintenance departments, through the process interviews, FGDs and so on, which are outlined in a written document which will be the basis for the preparation of the procurement document.

K. Soil test, schematic design, technical specifications, TOR, TOR, evaluation parameters for beauty contests for selecting integrated contractors, administrative and technical evaluation parameters, budget reviews based on accountable references.

L. If a construction management consultant has been appointed prior to the design and build contractor bidding, it is mandatory for contracted construction management personnel to provide input when reviewing all draft material prepared by the owner and also provide input on KPJ as tender material.

14. In the validity test which is considered invalid, it can be assumed that the variable is still not optimal in its application. The variables are:

A. The determination of the scope of work in a clear and detailed manner by a construction management consultant, 
B. Making design criteria together with employers, building users and building maintenance by a construction management consultant,

C. Making identification and land requirements by construction management consultants,

D. Making basic drawings, schematic drawings, section drawings, typical drawings and other drawings by construction management consultants,

E. Conducting a budget ceiling review by a construction management consultant,

15. If it is seen from the data that has been submitted by the expert that the use of construction management consultants at the procurement stage of building construction in Indonesia using this integrated construction method has been widely used, although some projects also involve a technical team.

\section{CONCLUSION}

a. Whereas the experts agree with the Regulation of the Minister of Public Works and Public Housing of the Republic of Indonesia No. 25 of 2020 concerning the procurement of integrated construction in which a construction management consultant is needed in the process. Where the construction management consultant must be supported by personnel who have good competence.

b. Whereas the documents that must be prepared by a construction management consultant for development activities using integrated construction methods are:

i. topographical documents,

ii. Soil/geological investigation data,

iii. Determination of the soil test point (as an initial reference) of the total soil test based on SNI,

iv. Define the scope of work clearly and in detail,

v. Make design criteria together with employers, building users and building maintenance departments,

vi. Prepare work standards to be carried out,

vii. Prepare quality standards,

viii. Prepare technical provisions for other service users,

ix. Identify and allocate project risks,

x. Make identification and land requirements,

xi. Making basic drawings, schematic drawings, cut drawings, typical drawings and other drawings, construction management consultants are strengthened by expert personnel with competence in the field of planning,

xii. Conducting a budget ceiling review,

xiii. Make a prediction of the activity period in the form of a project timeline.

c. From an analysis of the use of construction management consultants in projects that use integrated construction methods, it is found that most projects in Indonesia already involve construction management consultants, although some of them involve a technical team due to time considerations under certain conditions.

\section{REFERENCES}

1. PERMEN PU No. 45/PRT/M/2007. Technical Guidelines for the Construction of State Buildings. 37.

2. PERMEN PUPR No. 22/PRT/M/2018 Construction of State Buildings.

3. PERMEN PUPR No. 19/2015. Standards and Guidelines for Procurement of Integrated Construction Works Design and Build (Design And Build). 5.

4. PERMEN PUPR No. 12/PRT/M/2017. About Standards and Guidelines for Procurement of Integrated Construction Works Design and Build (Design And Build).

5. Presidential Regulation Number 16 of 2018. Regarding Government Procurement of Goods/Services.

6. Regulation of the Government Goods/Services Procurement Policy Institute Number 9 of 2018 concerning Guidelines for the Implementation of the Procurement of Goods/Services

7. Conditions of Contract for Plant \& Design-Build (First Ed, 1999)

8. The Importance of Construction Project Management in the Construction Industry (afifuddin Arifin, Anang Rifki Widyama, Danny Setiawan, 2016)

9. The Role of Construction Management in Projects (Lila Anggraini, ST, MT, 2015)

10. Study on the Role of Construction Management Consultants at Project Stages (Peter F Kaming1 and Ambar Y. Saputra ${ }^{2}$, 2013)

\section{AUTHORS}

First Author- Rubby Missilia Dwiaryanti, Master Candidate, Engineering and Construction Project Management, Faculty of Engineering, University of Persada Indonesia-YAI, Jakarta, Email: rubbymissilia@ gmail.com Phone +62 8111899399

Second Author- Dwi Dinariana (Dr), Mentor and Supervisor, Engineering and Construction Project Management, Faculty of Engineering, University of Persada Indonesia-YAI, Jakarta, Email: dwidinariana@ yahoo.com Phone +62 81223469477 
Third Author- Fitri Suryani (Dr), Mentor and Supervisor, Engineering and Construction Project Management, Faculty of Engineering, University of Persada Indonesia-YAI, Jakarta, Email: Suryani.fitri21@ yahoo.com Phone +62 85719214008 